\title{
Bulb Fresh Weight Mode of Inheritance in Onion (Allium cepa L.)
}

\author{
Nenad Pavlović · Dejan Cvikić · Jasmina Zdravković · Radiša Đorđević • \\ Milan Zdravković · Jelica Gvozdanović Varga · Đorđe Moravčević
}

\begin{abstract}
Summary: One of the most important traits of onion bulb is its bulb fresh weight. Also, this trait is in a group of morphological markers that, together with RAPD, represent the parameter of the most precise identification of onion genotype. For the purpose of this study, the chosen genotypes were: Makoi bronzi, Piroska, AC 101, Jasenicki crveni, Bukino beo. Also, they were of a different geographical origin. Method of full diallel without reciprocals was applied in order to obtain $F_{1}$ and $F_{2}$ generation. Field trial with parents and hybrids $F_{1}$ and $F_{2}$ generation was set in a random block system with five replications at the Institute for Vegetable Crops, Smederevska Palanka, Serbia. Considering all crossing combinations, superdomination and domination are the modes of inheritance for bulb fresh weight. The best general combiner was the line Makoi bronzi. The highest level of SCA in $F_{1}$ and $F_{2}$ generation was found in hybrid combination Makoi bronzi x Piroska. Also, this hybrid combination had the highest values of heterosis.

Keywords: Allium cepa, bulb, dominance, F1 hybrids, F2 hybrids, fresh weight, genotypes, mode of inheritance, onions, super-dominance
\end{abstract}

\section{Introduction}

Onion bulb is the most important part of the onion, from the market point of view, so the breeders of this crop have to be focused on its high quality. One of the most important traits of onion bulb is its weight. Also, this trait is in a group of morphological markers that, together with RAPD, represent the parameter of the most precise identification of onion genotype (Pavlović et al. 2012).

Weight of onion bulb implicates the size of the bulb. This trait along with the realized set per unit area, directly influences total yield. The size of the bulb is a variety trait influenced by the way of growth, edaphic and ecologic conditions (Pavlović et al. 2002).

Determining the mode of inheritance is of extreme importance for breeders (Ortiz et al. 2001). By determining the combining abilities the choice of parental lines for obtaining good commercial onion varieties and hybrids is narrowed. Evaluation of

N. Pavlović* · D. Cvikić · J. Zdravković · R. Đorđević · M. Zdravković

Institute for Vegetable Crops, Karađorđeva 71, 11420 Smederevska Palanka, Serbia

e-mail: npavlovicpb@gmail.com

J. Gvozdanović-Varga

Institute of Field and Vegetable Crops, Maksima Gorkog 30, 21000 Novi Sad, Serbia

Đ. Moravčević

University of Belgrade, Faculty of Agriculture, Nemanjina 6, 11080 Belgrade-Zemun, Serbia parental lines is the starting point for its further application in selection. The success of the selection depends on the gene determination of traits chosen as the aim of selection. Breeders can expect the positive answer in breeding with traits with high heterosis, which is important for the success in creating new varieties (Haydar et al. 2007, Zdravković et al. 2010, Singh et al. 2010, Pavlović et al. 2011).

\section{Material and Methods}

For the purposes of this study the parental lines were chosen from the Institute for Vegetable Crops onion germplasm collection. Genotypes were divergent, which was determined in previous studies (Pavlović 1999). Method of diallel cross was applied. Genotypes Makoi bronzi, Piroska, AC101, Jasenicki crveni, Bukino beo all of a different geographical origin were the subject of this study.

Field trial with parents and $\mathrm{F}_{1}$ and $\mathrm{F}_{2}$ hybrids was set in a random block system with five replications with 30 plants per replica. Sowing was done in containers (103 holes) on 15 February 2006 in greenhouse. Planting date was 4 April 2006 in the open field.

The mode of inheritance of the bulb fresh weight was evaluated by testing significance of mean values of $F_{1}$ hybrids and $F_{2}$ generation comparing to

Acknowledgements: This work was supported by the Ministry of Education, Science and Technological Development of the Republic of Serbia (Research Grant: TR-31027). 
parental average according to Borojević (1986). Segregation of the genetic variance was performed by applying the method of Hayman's (1954) and Mather and Jinks (1971), and the analysis of combining abilities was performed according to Griffing (1956), method 2, mathematic model 1, which besides parental lines includes $F_{1}$ and $F_{2}$ generation.

\section{Results and Discussion}

The results in Table 1 show that the average bulb fresh weight of parental lines was from $50.80 \mathrm{~g}$ (Jasenicki crveni) to $88.76 \mathrm{~g}$ (AC 101). Analysis of the average weight of onion in $F_{1}$ generation showed that the lowest bulb fresh weight was from $48.60 \mathrm{~g}$ (hybrid derived from Makoi bronzi x Jasenicki crveni crossing combination) to $165.30 \mathrm{~g}$ (Makoi bronzi x Piroska). In $\mathrm{F}_{2}$ generation, the lowest and the highest bulb fresh weight were in the same crossing combinations as in $\mathrm{F}_{1}$ generation.

Analysis of variation effect proves significant variation of this quantitative trait (Table 1). In parental lines, the line with lowest variability was Piroski $(9.49 \%)$ while AC101 (16.74\%) had the highest variability.
In $F_{1}$ generation the variability, expressed as a coefficient of variability $(\mathrm{Cv})$ had great interval of variation: from 1.66\% (Makoi bronzi x Bunkino beo) to 16.88\% (AC101 x Jasenicki crveni). Parameters of variability in $\mathrm{F}_{2}$ generation were higher: from $3.22 \%$ (AC101 x Jasenicki crveni) to $17.89 \%$ (Jasenicki crveni $x$ Bunkino beo). High variability of traits studied in our study was also found in Agič (1996) and Pavlović et al. (2002) who emphasized that the main reason of high variability was the impact of the outdoor conditions.

In study of the mode of inheritance of the bulb fresh weight in $\mathrm{F}_{1}$ hybrid, the following types were established: super-dominance, partial-dominance, dominance and intermediary. Super-dominance of better parent was the most common mode of inheritance and it was found in three hybrid combinations and then the dominance of better and worse parent (Table 1). In $\mathrm{F}_{2}$ generation different results were obtained (Table 1).

Extremely high heterosis in both generations was found in hybrid combination Makoi bronzi x Piroska. This hybrid had the highest bulb fresh weight. The significant heterosis was found in five other hybrids in both studied generations (Table 1).

Table 1. Mean value $(\overline{\mathbf{X}})$, standard error $(S x)$, variation coefficient $(C v)$, mode of inheritance, absolute and relative heterosis $(H a$ and $H r)$ for the average bulb fresh weight of researched lines, $F_{1}$ and $F_{2}$ hybrids of onion

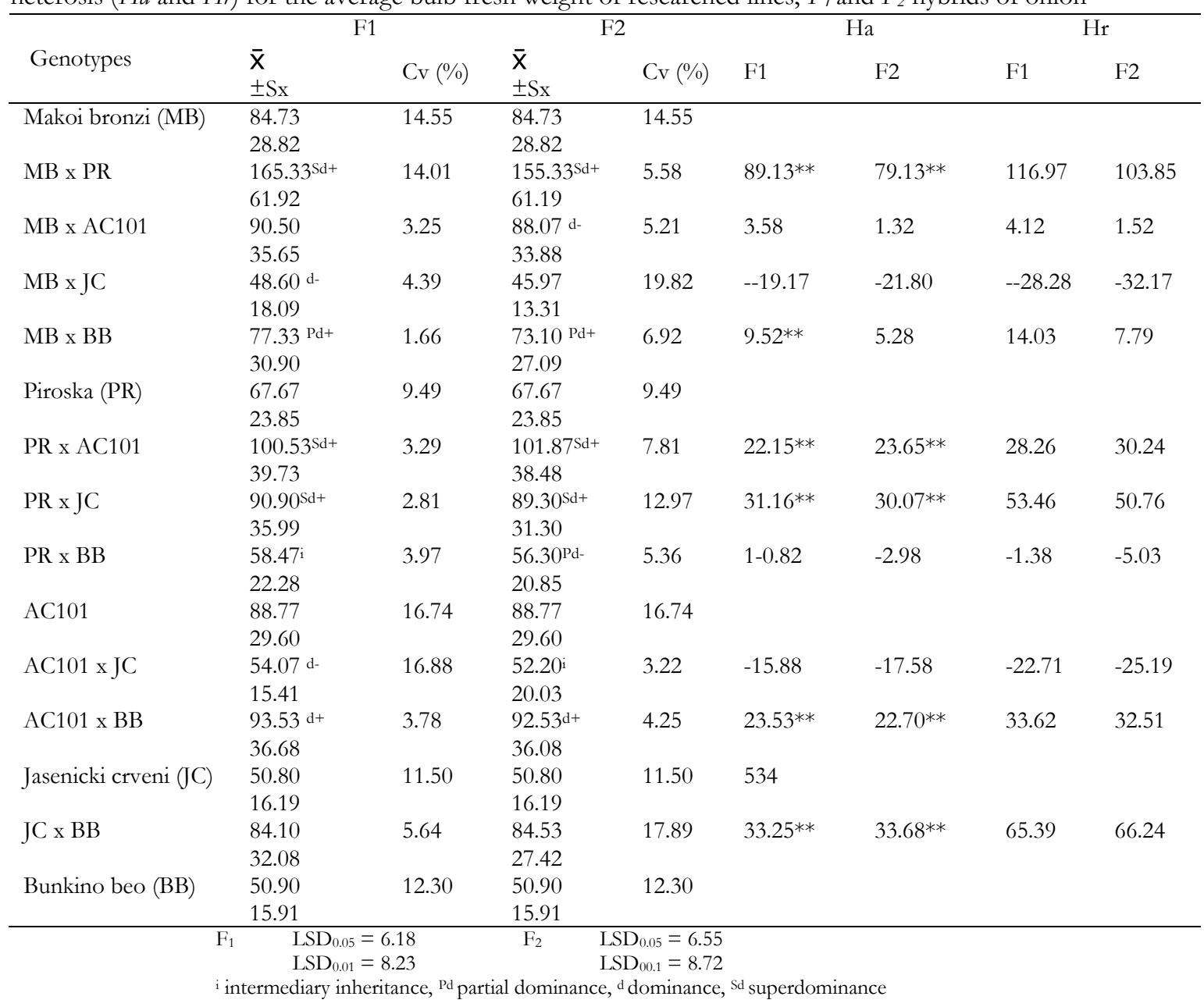


Additive component of genetic variance (D) for the studied trait was lower than dominant $\left(\mathrm{H}_{1}\right.$ and $\left.\mathrm{H}_{2}\right)$ in both generation levels, which proves that the heredity of bulb fresh weight was influenced by dominant genes.

Negative $F$ value (interaction of additive $x$ dominant gene effect) proves that the heredity of this trait was more influenced by recessive alleles. Also, this proves that the ratio of total number of dominant and recessive alleles $(\mathrm{Kd} / \mathrm{Kr}=0.95$ and 0.98$)$ was less than one. Dominant and recessive alleles were not equally positioned in parental lines $\left(\mathrm{H}_{2} / 4 \mathrm{H}_{1}=0.22\right.$, Table 2).

The average level of domination $\sqrt{H_{1} / D}(=3.25$ and 3.08) was higher than one, which proves the super-dominance as the mode of inheritance of bulb weight, regardless to the crossing combination.
Table 2. Components of genetic variance for content of the onion bulb fresh weight

\begin{tabular}{|c|c|c|}
\hline Components & Values $F_{1}$ & Values $F_{2}$ \\
\hline $\mathrm{D}$ & 319.713 & 319.125 \\
\hline $\mathrm{H}_{1}$ & 3380.539 & 3031.667 \\
\hline $\mathrm{H}_{2}$ & 3051.187 & 2752.742 \\
\hline $\mathrm{F}$ & -47.651 & -16.982 \\
\hline $\mathrm{E}$ & 4.781 & 5.369 \\
\hline $\mathrm{H} 2 / 4 \mathrm{H} 1$ & 0.226 & 0.227 \\
\hline$\sqrt{H_{1} / D}$ & 3.252 & 3.082 \\
\hline $\mathrm{Kd} / \mathrm{Kr}$ & 0.955 & 0.983 \\
\hline $\mathrm{hu}^{2}$ & 0.31 & 0.31 \\
\hline hš² & 0.99 & 0.99 \\
\hline
\end{tabular}

Table 3. Analysis of variance of combining abilities for the average onion bulb fresh weight

\begin{tabular}{|c|c|c|c|c|c|c|c|}
\hline \multirow{2}{*}{$\begin{array}{l}\text { Source of } \\
\text { variation }\end{array}$} & \multirow{2}{*}{ df } & \multicolumn{2}{|c|}{ (SS) } & \multicolumn{2}{|c|}{ (MS) } & \multicolumn{2}{|c|}{ F-exp } \\
\hline & & $\mathrm{F}_{1}$ & $\mathrm{~F}_{2}$ & $\mathrm{~F}_{1}$ & $\mathrm{~F}_{2}$ & $\mathrm{~F}_{1}$ & $\mathrm{~F}_{2}$ \\
\hline GCA & 4 & 3667.5 & 3331.8 & 916.9 & 832.9 & $191.8^{* *}$ & $155.1^{* *}$ \\
\hline SCA & 10 & 8542.4 & 7620.4 & 854.2 & 762.0 & $178.7^{* *}$ & $141.9^{* *}$ \\
\hline Error & 28 & & & 4.78 & 5.37 & & \\
\hline GCA/SCA & & & & 1.07 & 1.09 & & \\
\hline
\end{tabular}

Table 4. Value of GCA parental lines for the average onion bulb fresh weight

\begin{tabular}{|c|c|c|c|c|c|c|}
\hline Parents & $\begin{array}{l}\text { Values of } \\
\text { GCA F } 1\end{array}$ & Rank & $\mathrm{Se}$ & $\begin{array}{c}\text { B Value of } \\
\text { GCA F }_{2}\end{array}$ & Rank & $\mathrm{Se}$ \\
\hline $\mathrm{MB}$ & 9.820 & 1 & & 8.444 & 2 & \\
\hline PR & 9.725 & 2 & & 9.329 & 1 & \\
\hline AC101 & 4.811 & 3 & 1.169 & 5.625 & 3 & 1.238 \\
\hline JC & -14.747 & 5 & & -14.175 & 5 & \\
\hline $\begin{array}{l}\text { LS } \\
\text { LS } \\
\text { Se }\end{array}$ & $\begin{array}{l}.338 \\
.109 \\
\text { ard error }\end{array}$ & $\begin{array}{l}\mathrm{LSD}_{0.05}=2.447 \\
\mathrm{LSD}_{0.01}=3.294\end{array}$ & & & & \\
\hline
\end{tabular}

Table 5. Value of SCA F1 and F2 generation for the average bulb fresh weight

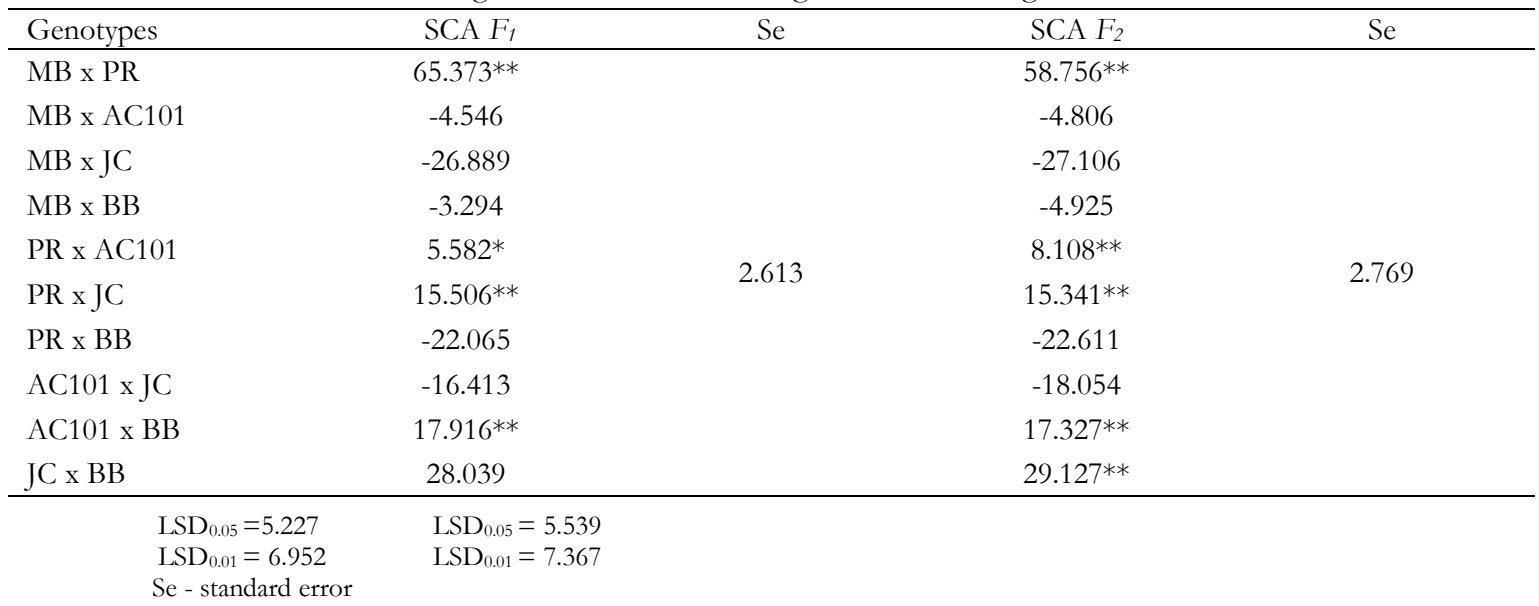


Heritability in narrow sense in $\mathrm{F}_{1}$ generation was 0.31 , and in broader 0.99. Similar values were found in $F_{2}$ generation. High values of heritability for the studied trait prove higher level of genetic factors in inheritance of the average bulb fresh weight. High level of heritability was also confirmed by Singh et al. (1995), Neykov et al. (1997), Pavlović et al. (2002).

The analysis of variance of combining abilities in our study proved significant values of GCA and SCA in both generations (Table 3). The GCA values were a little higher than SCA, which proves the dominant influence of additive genes in inheritance of bulb fresh weight. However, the influence of non-additive genes was extremely high.

The GCA values (Table 4) prove that the studied lines had statistically significant differences in both researched generations. The best GCA was found in line Makoi bronzi both in $F_{1}$ and $F_{2}$ generation, followed by Piroska and AC101, while lines Jasenicki crveni and Bunkino beo had statistically significant negative values of GCA.

The highest level of SCA in $\mathrm{F}_{1}$ generation was found in hybrid derived from the crossing combination Makoi bronzi x Piroska. Four other combinations had positive

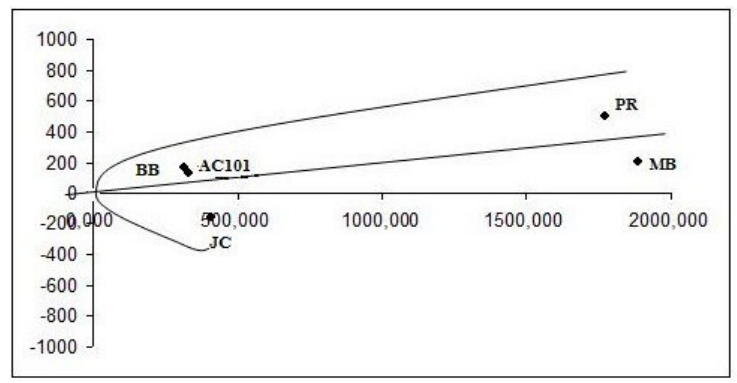

Figure 1. $V r W r$ regression for the average onion bulb fresh weight in $\mathrm{F}_{1}$ generation

\section{Conclusions}

The obtained results of our study show that both generations of hybrid combinations Makoi bronzi $x$ Piroska had the highest bulb fresh weight. Considering all crossing combinations, super-dominance and dominance are the mode of inheritance for bulb fresh weight. The best general combiner was the genotype Makoi bronzi. Hybrid Makoi bronzi x Piroska had the highest level of SCA in $\mathrm{F}_{1}$ and $\mathrm{F}_{2}$ generation. Also, this hybrid combination had the highest values of heterosis. significant values of SCA. Negative significant values were calculated in three hybrid combinations (Table 5). Almost identical values were found in $\mathrm{F}_{2}$ generation. These SCA values could be explained by equal participation of additive and non-additive genetic variance in inheritance onion bulb fresh weight.

Regression coefficient (b) was significantly different from 1 both in $F_{1}$ and $F_{2}$ generation, which proves the presence of inter-allele interaction of genes in inheritance of onion bulb weight.

Figures 1 and 2 show that the regression line was distant from the limiting parabola, which proves that the influence of non-additive genes was higher. The intersection of the expected regression line with $\mathrm{Wr}$ axis was above the coordinate start which proves partial domination as heredity mode of this trait (Figures 1 and 2).

Distribution of points at the diagram along the expected line of regression proves that genotypes chosen for the hybridization i.e. parental genotypes were genetically divergent.

Parental line with the greatest number of dominant genes in both generations was Bunkino beo, while the bearer of the largest number of recessive genes for the bulb fresh weight in both generations was Makoi bronzi.

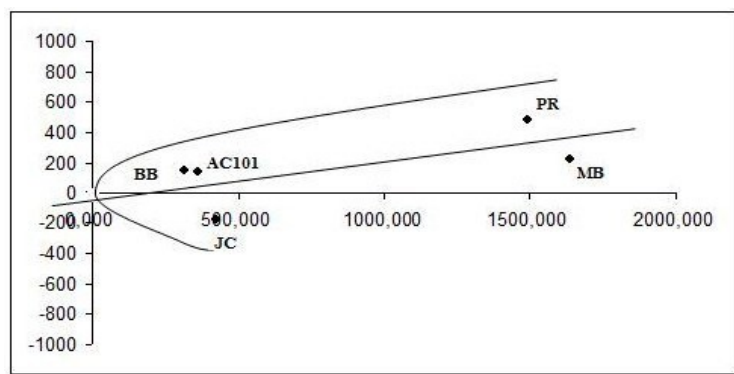

Figure 2. $V r W r$ regression for average bulb fresh weight in $\mathrm{F}_{2}$ generation

\section{References}

Agič, R. (1996). Sporedbeni ispituvana introduirani poluluti sorti kromid vo uslovi na skopsko. Master's Thesis, Faculty of Agriculture, Skopje, Makedonija.

Borojević, K. (1986). Genes and Population. Forum, Novi Sad (in Serbian)

Griffing, B. (1950). Concept of general and specific combining ability in relation to diallel crossing systems. Aust. J. Biol. Sci., 9: 463-493.

Haydar, A., Sharker, N., Ahmend, M.B., Hannan, M.M., Razvy, M.A., Hossain, M., Hoque, A., \& Karim, R. (2007). Genetic variability and interrelationship in onion (Allim cepa L.). Middle-East Journal of Scientific Research 2(3-4): 132-134.

Hayman, B. J. (1954). The theory and analysis of diallel crosses. Genetics, 39: 787-809.

Mather, K., \& Jinks, J.L. (1971). Biometrical Genetics. Sec. Ed., Chapman and Hall, London

Pavlović, N., Cvikić, D., Zdravković, J., Mijatović, M., \& BrdarJokanović, M. (2011). Mode of inheritance of dry matter content in onion (Allium cepa L.). Genetika, 43(1): 19-27.

Neykov, S., \& Ceschmedziev, I. (1997). Biodiversity, distribution and preservation of Allium spp. in Bulgaria. IPGRI on Allium. p. 80-83. 
Ortiz, R., Madsen, S., Wagoire, W.W., Hill, J., Chandra, S., \& Stolen, O. (2001). Additive main effect and multiplicative interaction mode for a diallel-cross analysis. Theoretical and Applied Genetics 101: 11031106.

Pavlović, N., Zdravković, J., \& Sretenović-Rajičić, T. (2002). Variability of onion bulb fresh weight. 1st Symposium on horticulture, p. 152, Ohrid, Macedonia.

Pavlović, N., Zdravković, J., Cvikić, D., Zdravković, M., Adžić, S., Pavlović, S., \& Surlan-Momirović, G. (2012). Mogućnost primene molekularnih RAPD markera u selekciji crnog luka. Genetika, 44 (2): 269-27.
Pavlović, N. (1999). Ocena selekcione vrednosti i divergentnosti germplazme u kolekciji crnog luka (Allium cepa L.). Master's Thesis. University of Belgrade, Faculty of Agriculture, Belgrade.

Singh, D.N., Nandi, A., Tripathy, P., \& Sahu, A. (1995). Genetic variability and correlation in onion (Allium cepa). Indian Journal of Agriculture Sciences 65(11): 793-796.

Singh, R.K., Dubey, B.K., Bhonde, S.R., \& Gupta, R.P. (2010). Variability studies for some quantitative characters in white onion (Allium cepa L.) advance lines. Vegetable Science 37(1): 105-107.

Zdravković, J., Pavlović, N., Girek, Z., Zdravković, M., \& Cvikić, D. (2010). Characteristics important for organic breeding of vegetable crops. Genetika, 42: 223-233.

\section{Način nasleđivanja mase lukovice crnog luka (Allium cepa L.)}

\section{Nenad Pavlović · Dejan Cvikić · Jasmina Zdravković · Radiša Đorđević · Milan Zdravković Jelica Gvozdanović Varga • Đorđe Moravčević}

Sažetak: Među najbitnije proizvodne osobine lukovice crnog luka ubraja se njena masa. Zatim, ova osobina spada u grupu morfoloških markera koja zajedno sa primenom molekularnih markera (RAPD), služi kao parametar za najtačniju identifikaciju genotipova crnog luka. U cilju ispitivanja načina nasleđivanja ove osobine izvršeno je ukrštanje između pet divergentnih genotipova crnog luka, različitog geografskog porekla. Primenjen je metod punog dialela bez recipročnih ukrštanja, radi dobijanja potomstva $\mathrm{F}_{1}$ i $\mathrm{F}_{2}$ generacije. Poljski ogled sa roditeljima i hibridima $\mathrm{F}_{1}$ i $\mathrm{F}_{2}$ generacije postavljen je po slučajnom blok sistemu u pet ponavljanja u Institutu za povrtarstvo, Smederevska Palanka. Uzevši u obzir sve kombinacije ukrštanja, može se zaključiti da superdominacija i dominacija predstavljaju način nasleđivanja mase lukovice. Najbolji opšti kombinator bila je linija Makoi bronzi. Najvišu vrednost za SCA u $F_{1}$ i $F_{2}$ generaciji imao je hibrid nastao ukrštanjem linija Makoi bronzi x Piroška. Takođe, ova hibridna kombinacija imala je i najveće izračunate vrednosti za heterozis.

Ključne reči: Allium cepa, crni luk, dominacija, F1 hibridi, F2 hibridi, genotipovi, lukovica, masa, način nasleđivanja, superdominacija 